\title{
Pengukuran Kemampuan Berpikir Kritis Mahasiswa Rekayasa Diploma 4 Politeknik Negeri Bandung melalui Percobaan Momen Inersia
}

\author{
Nani Yuningsih ${ }^{\text {a) }}$, Sri Suratmi ${ }^{\text {b) }}$ \\ Unit Pelayanan Mata Kuliah Umum, Politeknik Negeri Bandung \\ Email: a)nani.yuningsih@polban.ac.id, ${ }^{\text {b) }}$ srisuratmi_polban@yahoo.com
}

\begin{abstract}
Politeknik Negeri Bandung is one of the colleges that provides vocational education in science and technology emphasizing on its application capabilities. The applicability of education can be achieved either with critical thinking skills. The instruments of assessment through experiment of Moment of Inertia by using indicators capabilities through 4 levels of thinking, i.e.knowledge, comprehension, application, and analysis have been made to measure students' critical thinking skills. Assessment was conducted on student worksheets, i.e.the preliminary project, experiments, data processing, and reporting/journal writing. The questionnaires were used to assess the students' perceptions on Moment of Inertia module. It has been tested for validity and reliability. The entire statements have a validity coefficient greater than $0.3 \mathrm{r}$ critical, so all items statement can be used as a measuring tool in this research. While the value of reliability statement on that questionnaire is greater than 0.6. These results show that all statements on the questionnaire are reliable to measure the variables. The assessment results shows critical thinking skills of students with an average level of knowledge is $84 \%$, comprehensive is $84 \%$, application is $98 \%$, and for the analysis is $68 \%$. In this study, the Diploma 4 students have a good knowledge, good comprehension, have a high education applicapability and also good at analytical thinking.
\end{abstract}

Keywords: critical thinking, moment of inertia, student worksheets

\begin{abstract}
Abstrak
Politeknik Negeri Bandung adalah salah satu perguruan tinggi yang menyelenggarakan pendidikan vokasi dalam sejumlah bidang ilmu pengetahuan dan teknologi dengan mengutamakan kemampuan penerapannya. Kemampuan penerapan dapat dicapai salah satunya dengan kemampuan berpikir kritis. Untuk mengukur kemampuan berpikir kritis mahasiswa, telah dibuat instrumen penilaian melalui percobaan Momen Inersia dengan menggunakan indikator kemampuan melalui 4 tingkatan berpikir yaitu pengetahuan (knowledge), pemahaman (comprehensive), aplikasi (application), dan analisis (analysis). Penilaian dilakukan terhadap penilaian lembar kerja siswa (LKS) berupa tugas pendahuluan, pelaksanaan praktikum, pengolahan data, dan pembuatan laporan/jurnal praktikum. Untuk menilai persepsi mahasiswa terhadap percobaan Momen Inersia digunakan kuisioner yang telah diuji validitas dan reliabilitasnya. Seluruh item pernyataan memiliki koefisien validitas yang lebih besar dari r-kritis 0,3 , sehingga item-item tersebut layak digunakan sebagai alat ukur dalam penelitian dan nilai reliabilitas butir pernyataan pada kuesioner yang diteliti lebih besar dari 0,6. Hasil ini menunjukkan bahwa butir-butir pernyataan pada kuesioner andal untuk mengukur variabelnya. Hasil penilaian menunjukkan kemampuan berpikir kritis
\end{abstract}


mahasiswa dengan rata-rata tingkat pengetahuan $84 \%$, pemahaman $84 \%$, aplikasi $98 \%$, dan analisa 68\%. Hal ini menunjukkan bahwa mahasiswa Diploma 4 memiliki pengetahuan dan pemahaman yang baik, dan memiliki kemampuan aplikasi yang tinggi serta daya analisis yang baik.

Kata-kata kunci: berpikir kritis, momen inersia, LKS

\section{PENDAHULUAN}

Keterampilan berpikir kritis adalah kemampuan berpikir kompleks dengan menggunakan kemampuan berpikir berupa penalaran yang logis dan dapat diukur melalui tes objektif. Model pembelajaran ini mempunyai beberapa tahap pembelajaran. Tahap satu menyediakan area investigasi, yaitu mahasiswa dihadapkan kepada masalah. Tahap kedua mengumpulkan data untuk verifikasi. Tahap ketiga mengumpulkan data melalui kegiatan eksperimen. Tahap keempat merumuskan hasil eksperimen, dan tahap kelima adalah tahap terakhir yaitu melakukan analisis (Rubini 2008). Keterampilan berpikir kritis dapat diperoleh dari metode pembelajaran dengan kegiatan praktikum. Dimana selama kegiatan praktikum berlangsung mahasiswa dilatih untuk melakukan observasi, pertimbangan, identifikasi, dan menyimpulkan masalah yang dihadapi (Rubini 2008; Kurniati 2001).

Untuk mengembangkan keterampilan berpikir kritis pada generasi muda, seorang guru perlu menguasai keterampilan berpikir kritis untuk ditularkan kepada siswanya (Liliasari 2000). Model ini telah dikembangkan pada pembelajaran pendekatan keterampilan proses sains untuk meningkatkan keterampilan berpikir kritis siswa (Kurniati 2001). Keterampilan berpikir kritis menurut Ennis dalam Costa 1985 bahwa keterampilan berpikir kritis adalah kemampuan berpikir kompleks dengan menggunakan kemampuan berpikir berupa penalaran yang logis dan dapat diukur melalui tes objektif. Indikator keterampilan berpikir kritis dibagi menjadi lima kelompok yaitu memberikan penjelasan sederhana (elementery clarification), membangun keterampilan dasar (basic support), membuat inferensi (inference), membuat penjelasan lebih lanjut (advanced clarification), dan mengatur strategi dan taktik (strategies and tactics) (Rubini 2008).

Ciri-ciri seseorang mempunyai kemampuan berpikir kritis apabila seseorang dapat mengenal masalah dan menemukan cara-cara yang dapat dipakai untuk menangani masalah-masalah itu, mengumpulkan dan menyusun informasi yang diperlukan, mengenal asumsi-asumsi dan nilai-nilai yang tidak dinyatakan, memahami dan menggunakan bahasa yang tepat, jelas, dan khas, menilai fakta dan mengevaluasi pernyataan-pernyataan, mengenal adanya hubungan yang logis antara masalah-masalah, menarik kesimpulan-kesimpulan dan kesamaan-kesamaan yang diperlukan, menguji kesamaan-kesamaan dan kesimpulan-kesimpulan yang seseorang ambil, dan menyusun kembali pola-pola keyakinan seseorang berdasarkan pengalaman yang lebih luas (Fisher 2009).

Indikator keterampilan berpikir kritis dari ciri-ciri kemampuan berpikir kritis tersebut dapat diukur ketercapaiannya salah satunya melalui pembelajaran praktikum. Dari aspek proses belajar, melalui pengalaman melakukan praktikum/percobaan fisika, mahasiswa di didik untuk belajar mengambil kesimpulan dengan berbasis data dan analisis kritis, berpikir rasional, kritis dan mengambil keputusan berdasarkan data yang valid. Kemampuan berpikir kritis mahasiswa juga dapat diukur dengan instrumen penilaian terhadap setiap mahasiswa dengan menggunakan indikator kemampuan melalui 4 tingkatan berpikir yaitu pengetahuan (knowledge), pemahaman (comprehensive), aplikasi (application), dan analisis (analysis) (Bloom 1964).

Salah satu matakuliah dasar yang dapat meningkatkan keterampilan berpikir kritis mahasiswa Politeknik Negeri Bandung adalah praktikum Fisika Terapan. Pokok bahasan matakuliah Fisika Terapan yang banyak diperlukan untuk menunjang matakuliah jurusan adalah pokok bahasan Dinamika Gerak Rotasi. Pemahaman konsep tentang materi pokok bahasan gerak rotasi dengan pembelajaran dilengkapi praktikum model inkuiri terbimbing dapat meningkatkan keterampilan berpikir kritis pada mahasiswa dibandingkan dengan metode konvensional (Suratmi 2010).

Salah satu percobaan yang memadai untuk memfasilitasi materi gerak rotasi benda tegar adalah "Modul Momen Inersia Benda Tegar". 


\section{METODOLOGI PENELITIAN}

Metode yang digunakan dalam penelitian ini adalah metode analisis deskriptif. Instrumen penelitian terdiri atas alat untuk menentukan momen inersia, modul pembelajaran momen inersia, lembar kerja siswa (lembar kerja/job sheet), soal tes terdiri atas soal tugas pendahuluan dan soal pertanyaan akhir, lembar observasi, dan kuisioner.

Tingkat signifikan hasil pembelajaran praktikum terhadap peningkatan berpikir kritis mahasiswa dilakukan analisis dengan metoda eksperimen, sampel diambil 180 mahasiswa dari 6 program studi Diploma 4 yang mengontrak matakuliah Fisika Terapan pada semester Ganjil 2015/2016. Pengolahan data bersifat kuantitatif. Data kualitatif diperoleh dari hasil simpulan kuisioner, dan pengamatan keterampilan mahasiswa.

Untuk mengukur kemampuan berpikir kritis mahasiswa, dibuat instrumen penilaian terhadap setiap mahasiswa dengan menggunakan indikator kemampuan melalui 4 tingkatan berpikir yaitu pengetahuan (knowledge), pemahaman (comprehensive), aplikasi (application), dan analisis (analysis). Penilaian dilakukan terhadap penilaian tugas pendahuluan, pelaksanaan praktikum, pengolahan data, dan pembuatan laporan/jurnal praktikum. Indikator-indikator yang digunakan dapat dilihat pada TABEL 1 .

TABEL 1. Indikator Berpikir Kritis (Bloom 1964)

\begin{tabular}{cc}
\hline Tingkatan & Indikator \\
\hline Pengetahuan (Knowledge) & Menyebutkan \\
& Mendefinisikan \\
& Menggambarkan \\
\hline Pemahaman (Comprehensive) & Memeriksa \\
\hline Aplikasi (Application) & Membandingkan \\
& Membedakan \\
& Menjelaskan \\
Analisis (Analysis) & Memprediksi \\
& Menginterpretasikan \\
\hline & Menghitung \\
& Melakukan \\
& Mengembangkan \\
\hline & Menyusun \\
& Membandingkan \\
\hline
\end{tabular}

Berdasarkan indikator-indikator tersebut telah disusun evaluasi mahasiswa meliputi penilaian terhadap tugas pendahuluan, pengambilan data, pengolahan data, penyusunan kesimpulan, dan penulisan daftar pustaka dengan pembobotan sesuai dengan SOP (Standard Operational Procedure) yang berlaku di Laboratorium Fisika Terapan Polban.

\section{HASIL DAN PEMBAHASAN}

\section{Pengukuran Tingkat Pengetahuan (Knowledge)}

Penilaian tingkat pengetahuan dilakukan terhadap tugas pendahuluan termasuk didalamnya adalah penulisan daftar pustaka. Tugas pendahuluan ini merupakan bagian yang sangat penting sebagai persiapan untuk memulai percobaan. Dengan mengerjakan tugas pendahuluan, mahasiswa dituntut untuk mencari informasi (teori) yang mendukung percobaan yang akan dilakukan di laboratorium dan mengacu pada daftar pustaka. Hasil penilaian terhadap mahasiswa untuk tingkat pengetahuan dapat dilihat pada GAMBAR 1. 


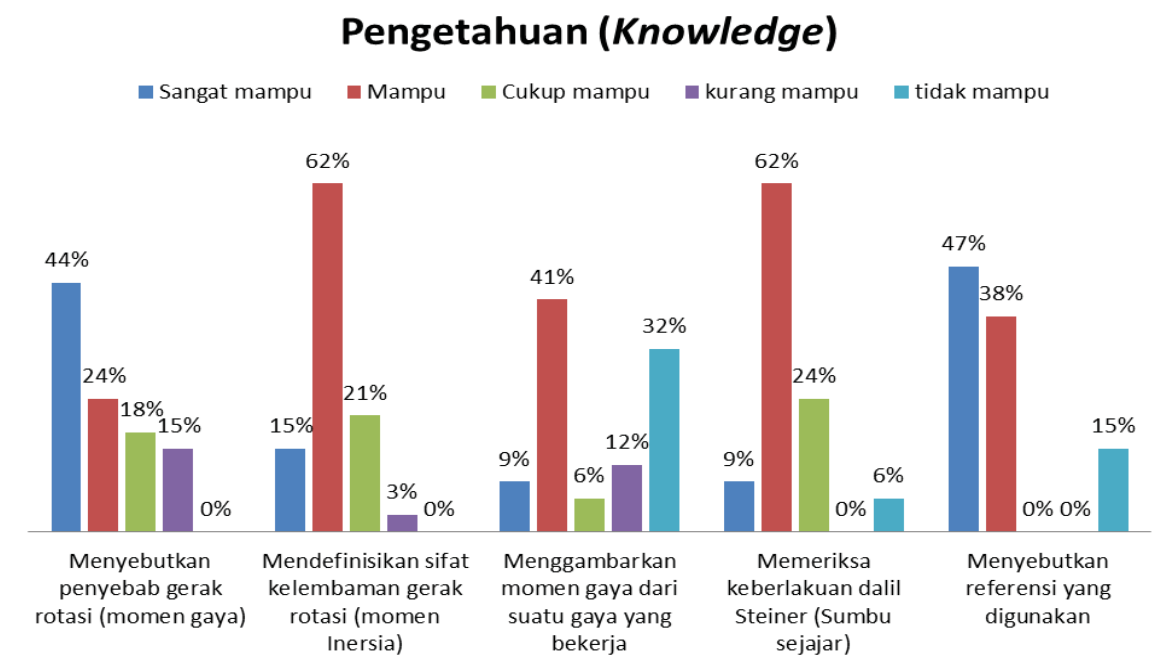

GAMBAR 1. Kemampuan berpikir kritis tingkat pengetahuan (knowledge)

Sebanyak 85\% mahasiswa mampu menyebutkan penyebab gerak rotasi, 97\% mampu menyebutkan definisi momen inersia sebagai sifat kelembaman gerak rotasi, 56\% mampu menggambarkan momen gaya dari suatu gaya yang bekerja, 94\% mampu memeriksa keberlakuan dalil Steiner, dan 85\% mampu menyebutkan referensi yang digunakan. Dari data tersebut dapat ditarik kesimpulan bahwa mahasiswa sudah memiliki pengetahuan yang baik tentang pokok bahasan Gerak Rotasi, subpokok bahasan Momen Inersia.

\section{Pengukuran Tingkat Pemahaman (Comprehensive)}

Penilaian tingkat pemahaman dilakukan terhadap tugas pendahuluan, pengambilan data, pengolahan data, dan pembuatan laporan/jurnal. Mahasiswa yang mampu membandingkan momen inersia berbagai bentuk benda sebanyak 90\%, 94\% mampu menjelaskan faktor-faktor yang berpengaruh terhadap momen inersia, namun hanya $51 \%$ yang mampu menjelaskan faktor-faktor penyebab ketidaksesuaian antara hasil percobaan dengan teori. Seluruh mahasiswa mampu memprediksi penambahan perioda akibat perubahan letak sumbu putar. Hasil penilaian terhadap mahasiswa untuk tingkat pemahaman dapat dilihat pada GAMBAR 2.

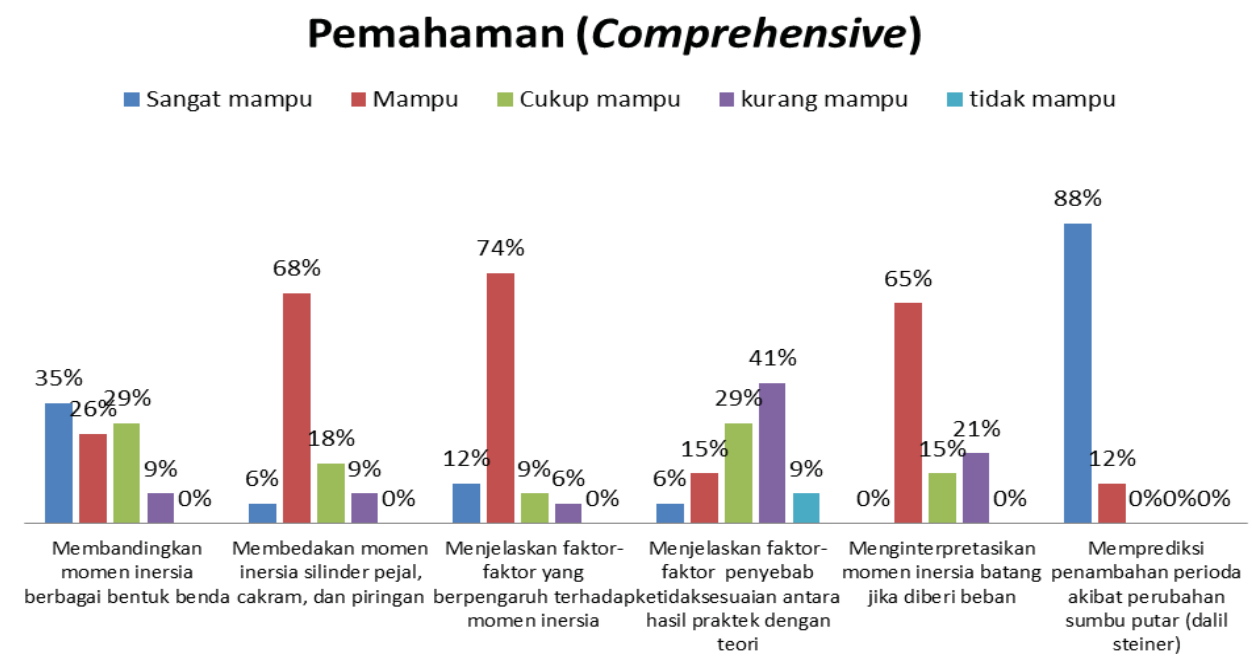

GAMBAR 2. Kemampuan berpikir kritis tingkat pemahaman (comprehensive) 


\section{Pengukuran Tingkat Aplikasi (Application)}

Penilaian tingkat aplikasi dilakukan saat pengambilan data dan pengolahan data. Seluruh mahasiswa mampu melaksanakan percobaan dengan benar dan menghitung momen inersia secara teori. Namun hanya $97 \%$ yang mampu menghitung momen inersia secara percobaan. Dari data tersebut dapat ditarik kesimpulan bahwa mahasiswa memiliki kemampuan tingkat aplikasi yang tinggi. Hasil penilaian terhadap mahasiswa untuk tingkat aplikasi dapat dilihat pada GAMBAR 3.

\section{Aplikasi (Application)}

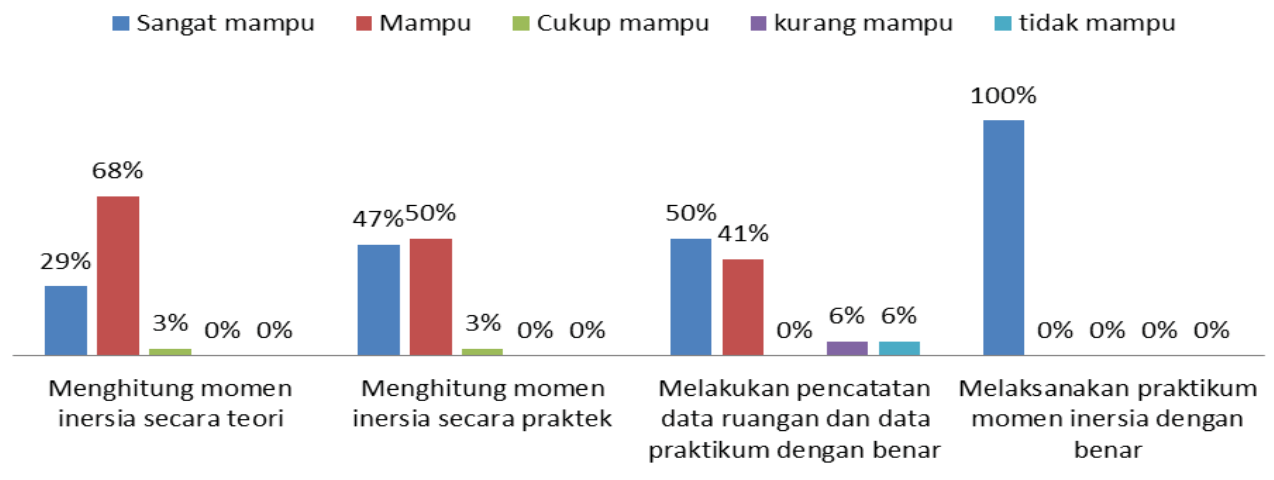

GAMBAR 3. Kemampuan berpikir kritis tingkat aplikasi (application)

\section{Pengukuran Tingkat Analisis (Analysis)}

Penilaian tingkat analisa dilakukan saat pengolahan data dan penyusunan laporan/jurnal. Seluruh mahasiswa mampu membandingkan momen inersia yang dihitung secara teori dan secara percobaan. Namun hanya $38 \%$ mahasiswa yang mampu menganalisis perbedaan antara momen inersia yang dihitung secara teori dan secara percobaan. Begitu juga dalam membuat kesimpulan, hanya $35 \%$ yang mampu membuat kesimpulan secara benar. Dari data tersebut dapat diambil kesimpulan bahwa mahasiswa masih memiliki tingkat analisa yang cukup baik. Hasil penilaian terhadap mahasiswa untuk tingkat pengetahuan dapat dilihat pada GAMBAR 4.

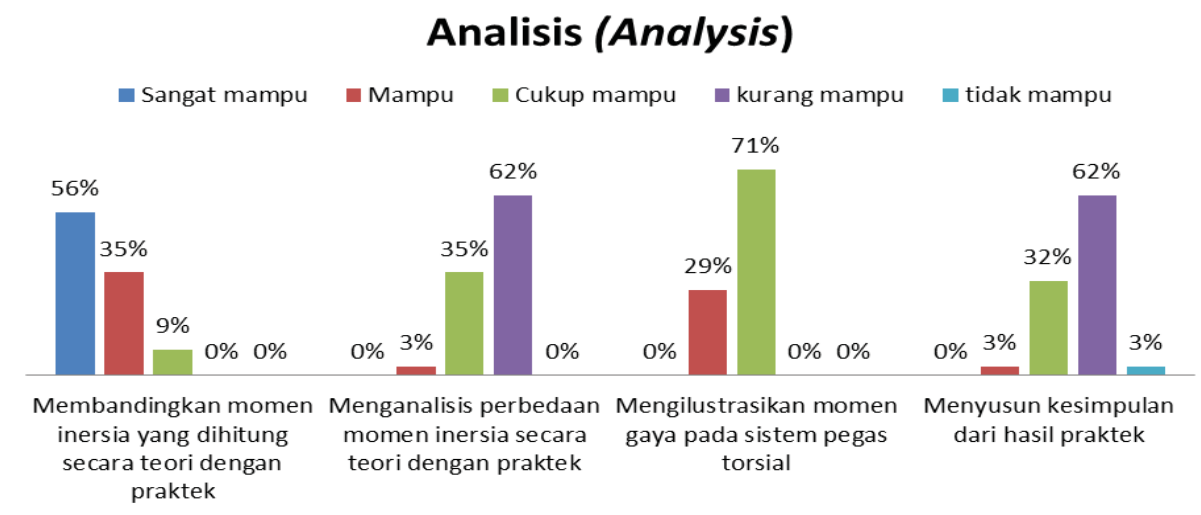

GAMBAR 4. Kemampuan berpikir kritis tingkat analisis (analysis)

Dari angket penilaian mahasiswa terhadap model pembelajaran Momen Inersia secara percobaan diperoleh hasil bahwa dengan pembelajaran praktikum, pemahaman tentang momen gaya sebagai penyebab gerak rotasi menjadi mudah dipahami. Begitu juga pemahaman tentang peranan momen inersia terhadap gerak rotasi menjadi lebih mudah dipahami.

Uji validitas dilakukan untuk menguji kesahihan setiap item pernyataan dalam mengukur variabelnya. Teknik korelasi yang digunakan untuk menguji validitas butir pernyataan dalam penelitian ini adalah Pearson Product Moment. Apabila nilai koefisien korelasi butir item pernyataan 
yang sedang diuji lebih besar dari r-kritis sebesar 0,3, dapat disimpulkan bahwa item pernyataan tersebut merupakan konstruksi (construct) yang valid. Dari hasil pengolahan kuisioner diperoleh bahwa seluruh item pernyataan memiliki koefisien validitas yang lebih besar dari r-kritis 0,3 , sehingga item-item tersebut layak digunakan sebagai alat ukur dalam penelitian.

Uji reliabilitas dilakukan dengan cara menguji coba instrument sekali saja, kemudian dianalisis dengan menggunakan metode Alpha-Cronbach. Kuesioner dikatakan andal apabila koefisien reliabilitas bernilai positif dan lebih besar dari pada 0,6. Adapun hasil dari uji reliabilitas dapat dilihat pada TABEL 2.

TABEL 2. Hasil Uji Reliabilitas Kuesioner Penelitian

\begin{tabular}{cccc}
\hline Variabel & Indeks Reliabilitas & Nilai Kritis & Keterangan \\
\hline Variabel $x$ & 0.752 & 0.6 & Reliabel \\
\hline
\end{tabular}

Nilai reliabilitas butir pernyataan pada kuesioner variabel yang sedang diteliti lebih besar dari 0,6. Hasil ini menunjukkan bahwa butir-butir peryataan pada kuesioner andal untuk mengukur variabelnya.

\section{SIMPULAN}

Pembelajaran momen inersia melalui percobaan dapat menumbuhkan kemampuan berpikir kritis mahasiswa. Dari hasil penilaian bahwa dengan percobaan momen inersia dapat menumbuhkan kemampuan berpikir kritis mahasiswa dengan rata-rata tingkat pengetahuan $84 \%$, rata-rata tingkat pemahaman $84 \%$, rata-rata tingkat aplikasi $98 \%$, dan rata-rata tingkat analisis $68 \%$. Hal ini menunjukkan bahwa dengan menggunakan modul percobaan Momen Inersia ini, mahasiswa diploma 4 memiliki pengetahuan dan pemahaman yang baik, dan memiliki kemampuan aplikasi yang tinggi serta daya analisa yang baik.

\section{UCAPAN TERIMAKASIH}

Terimakasih kepada Politeknik Negeri Bandung melalui Unit Penelitian dan Pengabdian kepada Masyarakat (UPPM) Polban yang telah mendanai penelitian ini dan kepada rekan-rekan pengajar Fisika Terapan Polban yang telah turut berkonstribusi dalam penelitian ini.

\section{REFERENSI}

Bloom, B 1964, 'Taxonomy of Educational: Cognitive and Affective Domains'. David Mc.Kay Company, New York.

Fisher, A 2009, 'Berpikir Kritis. Sebuah Pengantar', Erlangga, p 7.

Kurniati, T 2001, 'Pembelajaran Keterampilan Proses Sains untuk Meningkatkan Keterampilan Berpikir Kritis Siswa', Tesis PPS, UPI.

Liliasari 2000, 'Model Pembelajaran untuk Meningkatkan Keterampilan Berpikir Konseptual Tingkat Tinggi Calon Guru IPA', Proceeding Nasional Science Education Seminar, JICA-IMSTEP. State University of Malang, p 135-141.

Rubini, B 2008, 'Model Pembelajaran Ilmu Alamiah Dasar Untuk Meningkatkan Pemahaman Kemampuan Berpikir Kritis Serta Menanamkan Sikap Ilmiah Mahasiswa Non-IPA', Tesis PPS, UPI.

Suratmi, S 2010, 'Model Pembelajaran Inkuiri Terbimbing Pokok Bahasan Gerak Rotasi dapat Meningkatkan Berpikir Kritis pada Mahasiswa', Jurnal Sigma-Mu Vol. 2, No.1. 